\title{
東北地方太平洋沖地震による岩手，宮城，福島県沿岸域における 津波堆積物の供給源
}

\section{一 TOC/TN 比および安定硫黄同位体（ $\boldsymbol{\delta}^{34} \mathbf{S} ）$ を指標として—}

$\begin{array}{llllllll}\text { 奈 良 郁 子* } & \text { 渡 邊 } & \text { 隆 広* 掛 川 } & \text { 武** } \\ \text { 山 崎 慎 一* } & \text { 井 上 } & \text { 千 } & \text { 弘* } & \text { 土 屋 範 } & \text { 芳* }\end{array}$

Sources of Tsunami Deposits on the Pacific Coasts of Iwate, Miyagi, and Fukushima Areas by the 2011 off the Pacific Coast of Tohoku Earthquake, Northeast Japan Inferred from Geochemical Signatures (TOC/TN Ratio and Stable Sulfur Isotope)

\author{
Fumiko W. NARA*, Takahiro WATANABE*, Takeshi KAKEGAWA**, \\ Shin-ichi YAMASAKI*, Chihiro INOUE* and Noriyoshi TSUCHIYA*
}

[Received 6 March, 2014; Accepted 5 September, 2014]

\begin{abstract}
Geochemical analyses (total nitrogen: TN, total organic carbon: TOC, total sulfur: TS, and stable sulfur isotope ratio: $\delta^{34} \mathrm{~S}$ ) were performed on tsunami deposits by the 2011 off the Pacific coast of Tohoku Earthquake obtained from Iwate, Minamisanriku, Kesen-numa, and Sendai Bay areas for a total of 133 samples. Although TOC/TN ratios ranged widely (0.7-90), most of the samples (more than $80 \%$ of samples) ranged from 10-30, which were similar results to those for marine surface sediment in the Pacific coast area. Low $\delta^{34} \mathrm{~S}$ values (from $-29.6 \%$ to $-11.3 \%$ ) from Iwate, Minami Sanriku, and Sendai Bay tsunami deposits were observed. Generally, such low $\delta^{34} \mathrm{~S}$ values result from large isotope fractionation caused by the activity of sulfate-reducing bacteria in marine sediment under a sulfate $\left(\mathrm{SO}_{4}{ }^{2-}\right)$ rich environment. These results suggest that the tsunami deposits were mainly derived from marine sediment. High correlations between TS and As contents $(r=0.958)$ were observed in tsunami deposits from the Kesen-numa area. Furthermore, the high $\delta^{34} \mathrm{~S}$ values (from $-3.1 \%$ to $-0.7 \%$ ) in the tsunami deposits from the Kesen-numa area correspond well with those of hydrothermal ore samples from the Kesen-numa area. These results indicate that sulfur and arsenic in tsunami deposits from the Kesen-numa area originated in slag from the mines.
\end{abstract}

Key words : TOC/TN ratio, stable sulfur isotope, sulfate reducing bacteria, tsunami deposits, The 2011 off the Pacific coast of Tohoku Earthquake

キーワード : TOC/TN 比, 安定硫黄同位体, 硫酸還元バクテリア, 津波堆積物, 東北地方太平洋沖 地震

\footnotetext{
$*$ 東北大学大学院環境科学研究科

*** 東北大学大学院理学研究科地学専攻

* Graduate School of Environmental Studies, Tohoku University, Sendai, 980-8579, Japan

** Department of Earth Science, Tohoku University, Sendai 980-8576, Japan
} 


\section{I. はじめに}

地震によって発生した陸域の津波浸水域を推定 するために，地層中に残された津波堆積物を発見 する試みがこれまで多く行われてきた（例えば， 藤原, 2007; 藤原ほか, 2013)。なかでも仙台平野 にて採取された津波堆積物試料を用いた研究は, 非常に活発に行われている（Minoura and Nakaya, 1991; 澤井ほか, 2006; 菅原ほか, 2011)。東 北地方において，過去に発生した地震（貞観地 震，西暦 869 年）により引き起こされた巨大津 波により，仙台平野が浸水し津波堆積物を形成さ せたことがわかっている（Minoura and Nakaya， 1991; 澤井ほか, 2006; 菅原ほか, 2011)。地層中 からの津波堆積物の認定は, 多くの場合, 海岸の 砂由来と考えられる石英質の砂層を見いだすこと により決定される（例えば, 澤井ほか, 2006)。と くに，仙台平野で確認された津波堆積物である 「貞観津波堆積物」は，歴史記録に残された津波 被害 (貞観地震) との整合をもち，災害科学にお ける津波堆積物研究の重要性を示している。しか しながら， 2011 年に発生した東北地方太平洋沖 地震後のフィールド調査から，海から陸域へと運 搬された津波堆積物は, 砂よりもさらに粒度の細 かい泥質の堆積物が，砂と比較してさらに内陸へ と運搬されていることがわかった（Goto et al., 2011)。Goto et al.（2011）は，歴史津波堆積物 中の砂層から見積もられた津波浸水域は, 実際よ りも小さく見積もられている可能性を指摘してい る。つまり，砂層津波堆積物のみで評価された津 波浸水域は，実際の津波浸水域を過小評価する恐 れがある。粒度に関するデー夕のみではなく,さ まざまな指標を用いて津波堆積物の分析を進め, 基礎デー夕を蓄積していくことが重要であること は間違いない。

2011 年東北地方太平洋沖地震により陸域へ打 ち上げられた津波堆積物試料を用いて，さまざま な地球化学分析が進められている (Chagué-Goff et al., 2012; 土屋ほか, 2012; 渡邊ほか, 2014)。 土屋ほか $(2012)$ は，2011 年 4 月から 8 月にか けて, 岩手県久慈市から福島県南相馬までの津波
浸水域から津波堆積物試料を採取した。津波堆積 物中の無機金属元素およびヒ素の含有量の分析か ら，津波により海底および河口付近の堆積物が陸 域へ打ち上げられ，津波を起因とした陸域におけ るヒ素の環境リスクが増加することを示した。

本研究では, 2011 年 3 月の東北地方太平洋沖地 震による津波で打ち上げられた堆積物試料中の全 窒素 (Total nitrogen: TN), 全有機態炭素 (Total organic carbon: TOC), 全硫黄 (Total sulfur: TS）含有量および安定硫黄同位体比（Stable sulfur isotope ratio: $\left.\delta^{34} \mathrm{~S}\right)$ の分析を行い, 津波堆積 物の供給源の推定を行った。安定硫黄同位体を用 いた現世津波堆積物の研究は, 仙台平野に打ち上 げられた津波堆積物試料（海岸から内陸域へ全長 $4.5 \mathrm{~km}$ ) を用いて行われているが (Chagué-Goff et al., 2012)，東北地方沿岸域全域を対象に安定硫 黄同位体分析を行ったのは，本研究がはじめてで ある。津波が引き起こす物質循環過程への影響に 関して, 地球化学分析結果に基づき報告を行う。

\section{II. 試料と分析方法}

\section{1) 試料}

本研究では, 岩手県久慈市から宮城県沿岸域の 全域，および福島県南相馬市までの津波浸水域に おいて採取された津波堆積物試料（試料数 133 個, 図 1，表 1）を分析に用いた。津波堆積物採取に関 する詳細は，既報（土屋ほか, 2012）を参照された い。特筆事項として, 鉱さい試料 (Slag sample, 試料名；NH1，NT30）を気仙沼市本吉町大谷地 区から採取した。ここでは，東北地方太平洋沖地 震により鉱山跡地の堆積場から，製錬時の廃棄物 である鉱さいが流出した。大谷地区での津波試料 採取時に, 明らかに堆積場から流出した人為由来 の鉱さい試料 2 点を採取した。

津波堆積物試料を風乾にて乾燥後, $2 \mathrm{~mm}$ の篩 を用いてレキ，木片等を除去した。粒径 $2 \mathrm{~mm}$ 未満の津波堆積物試料をメノウ乳鉢で均一化した 後，元素分析および安定同位体分析に供与した。

\section{2）窒素, 炭素, 硫黄元素分析}

津波堆積物中の全窒素含有量（Total nitrogen: $\mathrm{TN}$ ), 全有機態炭素含有量 (Total organic carbon: 


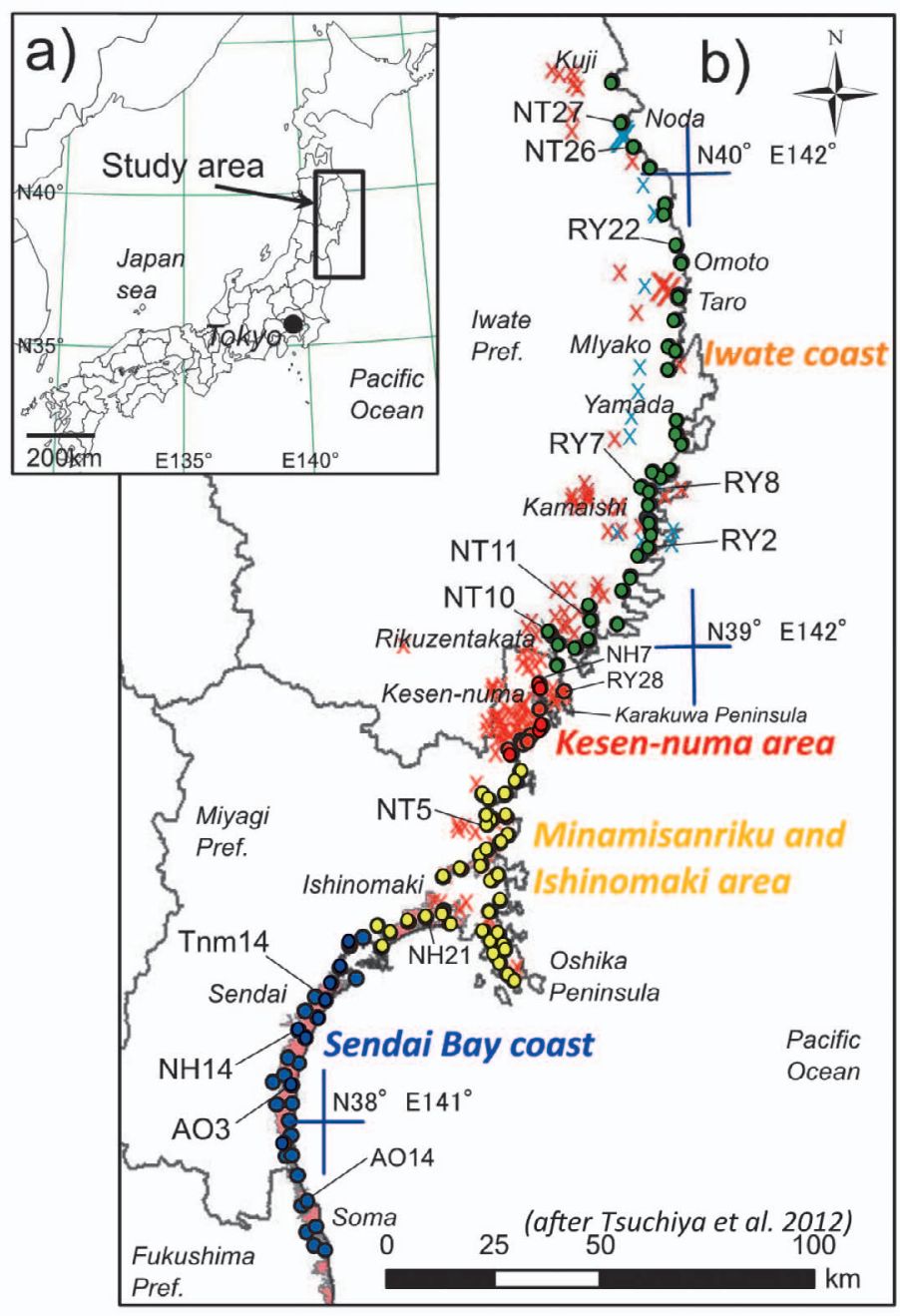

図 1 東北地方太平洋沿岸域に扔ける津波堆積物試料採取位置. a) 東北地方位置図, b) 東北地方太平洋沿岸図. 図 b 中の X印は赤色が鉱床，青色がBedded Mn を，また津波浸水域を橙色で記す.

Fig. 1 Map showing study area in Tohoku Pacific coast area. a) Tohoku district in Japan and b) sampling sites in Tohoku Pacific coast area. Red and blue X marks indicate sites of hydrothermal metal deposits and bedded Mn. The tsunami flooded area is shown with light red shading on the map.

TOC）および全硫黄含有量（Total sulfur: TS）の 定量分析は，東北大学に設置された元素分析計 (Elemental analyzer: EA, Flash 2000, ThermoFisher Scientific 社製）を用いた。TOC 分析に おいては, $1.2 \mathrm{~N}-\mathrm{HCl}$ により無機態炭素（炭酸塩） を除去した。津波堆積物試料を 10-15 mg 科量し錫 箔に封入後，元素分析計へ供与した。錫箔に封入
された試料は，約 $900^{\circ} \mathrm{C} に$ 設定された元素分析装置 内にて，酸素䨌囲気下で閃光燃焼される。その際， 温度が約 $1800^{\circ} \mathrm{C}$ 付近まで達することにより，試料中 の窒素, 炭素, 硫黄がガス化 $\left(\mathrm{N}_{2}, \mathrm{CO}_{2}, \mathrm{SO}_{2}\right)$ さ れる。これらの混合ガスはキャリアーガス（高純度 He）によって移動し，分離カラムにてそれぞれのガ スに分離後, 熱伝導度検出器（Thermal conduc- 
表 1 岩手沿岸, 気仙沼, 南三陸および石巻, 仙台港地域における津波堆積物試料中の全窒素 (TN), 全有機態炭素 (TOC), 全硫黄 $(\mathrm{TS})$ 含有量, TOC/TN 比, 安定硫黄同位体比 $\left(\delta^{34} \mathrm{~S}_{\mathrm{TS}}\right)$ ， 七素含有量. 七素含有量は土屋ほか $(2012)$ より引用した。

Table 1 TN, TOC and TS concentrations, TOC/TN atomic ratio, $\delta^{34} \mathrm{~S}$ and Arsenic (As) concentrations (after Tsuchiya et al., 2012) of bulk tsunami sediments.

\begin{tabular}{|c|c|c|c|c|c|c|c|c|c|c|}
\hline $\begin{array}{l}\text { sample } \\
\text { name }\end{array}$ & $\begin{array}{l}\text { sampling } \\
\text { point }\end{array}$ & $\begin{array}{l}\text { sampling } \\
\text { date }\end{array}$ & $\begin{array}{r}\mathrm{TN} \\
\mathrm{wt} \%\end{array}$ & $\begin{array}{l}\text { TOC } \\
\text { wt } \%\end{array}$ & $\begin{array}{l}\mathrm{TOC} / \mathrm{TN} \\
\text { atomic } \\
\text { ratio }\end{array}$ & $\begin{array}{c}\mathrm{TS} \\
\mathrm{wt} \%\end{array}$ & $\begin{array}{c}\delta_{\%}^{34} \mathrm{~S} \\
\% 0\end{array}$ & $\begin{array}{l}\text { Total As content } \\
\text { (Tsuchiya et al., } \\
\text { 2012) } \mathrm{mg} / \mathrm{kg}\end{array}$ & & Japanese address \\
\hline NT28 & 1 & 2011.7 .6 & 0.04 & 0.60 & 15.8 & 0.08 & & 9.1 & 岩手県 & 久慈市長内町 \\
\hline NT27 & 2 & 2011.7 .6 & 0.22 & 2.59 & 14.0 & 0.05 & & 29.4 & 岩手県 & 九戸郡野田村野田 \\
\hline NT26 & 3 & 2011.7.6 & 0.04 & 0.35 & 10.5 & 0.03 & & 12.2 & 岩手県 & 九戸郡野田村下安家 \\
\hline NT25 & 4 & 2011.7.6 & 0.02 & 0.11 & 8.0 & 0.01 & & 2.9 & 岩手県 & 下閉伊郡普代村宇留部 \\
\hline NT24 & 5 & 2011.7.6 & 0.02 & 0.28 & 17.0 & 0.01 & & 4.2 & 岩手県 & 下閉伊郡田野畑村羅賀 \\
\hline NT23 & 6 & 2011.7 .6 & 0.01 & 0.15 & 17.0 & 0.02 & & 3.8 & 岩手県 & 下閉伊郡田野畑村松前沢 \\
\hline RY22 & 7 & 2011.6 .15 & 0.16 & 3.91 & 28.0 & 0.13 & & 46.2 & 岩手県 & 下閉伊郡岩泉町小本小本 \\
\hline RY21 & 8 & 2011.6 .15 & 0.19 & 0.47 & 2.8 & 0.03 & & 4.7 & 岩手県 & 宮古市田老星山 \\
\hline RY20 & 9 & 2011.6 .15 & 0.03 & 0.47 & 16.1 & 0.08 & & 13.5 & 岩手県 & 宮古市田老乙部 \\
\hline RY19 & 10 & 2011.6.15 & 0.06 & 1.29 & 25.1 & 0.18 & & 6.8 & 岩手県 & 宮古市田老川向 \\
\hline RY18 & 11 & 2011.6.15 & 0.08 & 0.67 & 10.4 & 0.02 & & 4.2 & 岩手県 & 宮古市崎山第 4 地割 \\
\hline RY17 & 12 & 2011.6.15 & 0.07 & 0.65 & 10.9 & 0.12 & & 7.3 & 岩手県 & 宮古市小山田 \\
\hline RY16 & 13 & 2011.6 .15 & 0.03 & 0.57 & 22.4 & 0.03 & & 4.3 & 岩手県 & 宮古市磯鶏 2 丁目 \\
\hline RY15 & 14 & 2011.6.15 & 0.08 & 0.43 & 6.4 & 0.07 & & 6.4 & 岩手県 & 宮古市津軽石 \\
\hline RY14 & 15 & 2011.6.14 & 0.03 & 0.52 & 22.0 & 0.03 & & 1.7 & 岩手県 & 下閉伊郡山田町大沢 \\
\hline RY13 & 16 & 2011.6.14 & 0.02 & 1.70 & 90.2 & 0.06 & & 2.2 & 岩手県 & 下閉伊郡山田町織笠 \\
\hline RY12 & 17 & 2011.6.14 & 0.11 & 4.17 & 43.5 & 0.07 & & 8.2 & 岩手県 & 下閉伊郡山田町船越 \\
\hline RY11 & 18 & 2011.6.14 & 0.10 & 1.72 & 20.9 & 0.05 & & 5.4 & 岩手県 & 上閉伊郡大槌町吉里吉里 3 丁目 \\
\hline RY09 & 19 & 2011.6.14 & 0.16 & 2.06 & 14.7 & 0.12 & & 12.8 & 岩手県 & 上閉伊郡大槌町大槌第 15 地割 \\
\hline RY10 & 20 & 2011.6.14 & 0.08 & 0.91 & 12.8 & 0.20 & & 9.1 & 岩手県 & 上閉伊郡大槌町安渡 3 丁目 \\
\hline RY07 & 21 & 2011.6.14 & 0.38 & 4.94 & 15.1 & 0.13 & & 29.8 & 岩手県 & 釜石市鵜住居町第 5 地割 \\
\hline RY08 & 22 & 2011.6.14 & 0.23 & 2.30 & 11.8 & 0.30 & -16.9 & 40.3 & 岩手県 & 釜石市鵜住居町第 15 地割 \\
\hline RY06 & 23 & 2011.6.14 & 0.21 & 3.13 & 17.4 & 0.10 & & 14.2 & 岩手県 & 釜石市両石町水海 \\
\hline RY04 & 24 & 2011.6.14 & 0.23 & 4.79 & 24.3 & 0.46 & -11.3 & 24.9 & 岩手県 & 釜石市大渡町 1 丁目 \\
\hline RY05 & 25 & 2011.6 .14 & 0.20 & 3.81 & 22.5 & 0.65 & -18.1 & 15.0 & 岩手県 & 釜石市港町 1 丁目 \\
\hline RY03 & 26 & 2011.6.14 & 0.14 & 2.07 & 17.1 & 0.14 & & 9.4 & 岩手県 & 釜石市平田 \\
\hline RY02 & 27 & 2011.6.14 & 0.27 & 3.85 & 16.7 & 0.06 & & 11.1 & 岩手県 & 釜石市唐丹町本郷 \\
\hline RY01 & 28 & 2011.6.14 & 0.09 & 1.07 & 13.6 & 0.04 & & 5.1 & 岩手県 & 釜石市唐丹町荒川 \\
\hline RY32 & 29 & 2011.8 .2 & 0.13 & 0.68 & 6.0 & 0.03 & & 6.1 & 岩手県 & 大船渡市三陸町吉浜上野 \\
\hline RY31 & 30 & 2011.8.2 & 0.04 & 0.49 & 14.4 & 0.01 & & 4.1 & 岩手県 & 大船渡市三陸町越喜来沖田 \\
\hline RY30 & 31 & 2011.8.2 & 0.22 & 2.35 & 12.3 & 0.24 & & 14.8 & 岩手県 & 大船渡市三陸町綾里平舘 \\
\hline NT12 & 32 & 2011.6.16 & 0.11 & 3.21 & 33.4 & 0.35 & -17.3 & 9.2 & 岩手県 & 大船渡市赤崎町諏訪前 \\
\hline NT13 & 33 & 2011.6 .16 & 0.04 & 0.62 & 20.1 & 0.03 & & 13.8 & 岩手県 & 大船渡市末崎町神坂 \\
\hline NT10 & 34 & 2011.6.16 & 0.16 & 1.92 & 13.9 & 0.06 & & 18.9 & 岩手県 & 陸前高田市竹駒町十日市場 \\
\hline NT9 & 35 & 2011.6 .16 & 0.06 & 0.85 & 16.2 & 0.07 & & 11.3 & 岩手県 & 陸前高田市高田町中川原 \\
\hline NT8 & 36 & 2011.6.16 & 0.03 & 0.39 & 17.9 & 0.05 & & 11.8 & 岩手県 & 陸前高田市高田町古川 \\
\hline NT14 & 37 & 2011.6 .16 & 0.04 & 0.67 & 21.2 & 0.15 & & 11.9 & 岩手県 & 陸前高田市小友町三日市 \\
\hline RY29 & 38 & 2011.8 .2 & 0.11 & 0.97 & 10.2 & 0.03 & & 9.8 & 宮城県 & 気仙沼市唐桑町港 \\
\hline RY28 & 39 & 2011.8.2 & 0.10 & 0.94 & 11.2 & 0.02 & & 80.6 & 宮城県 & 気仙沼市唐桑町明戸 \\
\hline NH7 & 40 & 2011.6.1 & 0.16 & 2.21 & 16.4 & 0.51 & -11.0 & 20.0 & 宮城県 & 気仙沼市東八幡前 \\
\hline NH5 & 41 & 2011.6 .1 & 0.06 & 0.75 & 15.9 & 0.09 & & 15.4 & 宮城県 & 気仙沼市東みなと町 \\
\hline NH6 & 42 & 2011.6 .1 & 0.05 & 0.59 & 14.6 & 0.16 & & 11.7 & 宮城県 & 気仙沼市東みなと町 \\
\hline Tnm-05 & 43 & 2011.4.16 & 0.05 & 0.72 & 15.8 & 0.18 & & 11.5 & 宮城県 & 気仙沼市錦町 2 丁目 \\
\hline RY27 & 44 & 2011.8.2 & 0.04 & 0.30 & 8.4 & 0.02 & & 16.4 & 宮城県 & 気仙沼市松崎尾崎 \\
\hline RY26 & 45 & 2011.8 .2 & 0.14 & 1.36 & 11.2 & 0.04 & & 14.4 & 宮城県 & 気仙沼市波路上内田 \\
\hline NT35 & 46 & 2011.8.24 & 0.06 & 0.24 & 4.7 & 0.01 & & 12.0 & 宮城県 & 気仙沼市波路上杉ノ下 \\
\hline RY25 & 47 & 2011.8.2 & 0.23 & 2.52 & 12.7 & 0.03 & & 102.9 & 宮城県 & 気仙沼市本吉町九多丸 \\
\hline NT34 & 48 & 2011.8.24 & 0.21 & 1.60 & 9.0 & 0.04 & & 33.0 & 宮城県 & 気仙沼市本吉町田の沢 \\
\hline NT33 & 49 & 2011.8.24 & 0.23 & 0.92 & 4.7 & 0.05 & & 201.0 & 宮城県 & 気仙沼市本吉町前浜 \\
\hline NH1 & 50 & 2011.6 .1 & 0.02 & 0.31 & 18.6 & 1.43 & -3.3 & 2563.3 & 宮城県 & 気仙沼市本吉町高（鉱さい） \\
\hline NT30 & 51 & 2011.8.24 & 0.09 & 1.35 & 17.5 & 0.97 & -1.0 & 2257.4 & 宮城県 & 気仙沼市本吉町高（鉱さい） \\
\hline NH2 & 52 & 2011.6 .1 & 0.06 & 0.95 & 19.5 & 0.71 & -0.6 & 1735.4 & 宮城県 & 気仙沼市本吉町高 \\
\hline NT29 & 53 & 2011.8.24 & 0.13 & 1.15 & 10.5 & 0.43 & -1.1 & 1118.6 & 宮城県 & 気仙沼市本吉町高 \\
\hline NH3 & 54 & 2011.6 .1 & 0.13 & 1.93 & 17.1 & 0.68 & -1.2 & 1840.4 & 宮城県 & 気仙沼市本吉町高 \\
\hline NT31 & 55 & 2011.8.24 & 0.12 & 1.50 & 14.5 & 1.03 & -0.8 & 2202.6 & 宮城県 & 気仙沼市本吉町高 \\
\hline Tnm-06 & 56 & 2011.4.16 & 0.07 & 0.98 & 15.3 & 1.14 & -0.9 & 1984.8 & 宮城県 & 気仙沼市本吉町高 \\
\hline NH4 & 57 & 2011.6.1 & 0.10 & 1.56 & 18.1 & 0.04 & & 226.5 & 宮城県 & 気仙沼市本吉町赤牛 \\
\hline NT32 & 58 & 2011.8.24 & 0.11 & 2.11 & 22.3 & 0.24 & & 474.5 & 宮城県 & 気仙沼市本吉町赤牛 \\
\hline NT36 & 59 & 2011.8 .24 & 0.23 & 2.24 & 11.4 & 0.17 & & 26.1 & 宮城県 & 気仙沼市本吉町津谷明戸 \\
\hline Tnm-07 & 60 & 2011.4.16 & 0.44 & 0.27 & 0.7 & 0.23 & & 20.9 & 宮城県 & 気仙沼市本吉町卯名沢 \\
\hline
\end{tabular}


表 1 (つづき)

Table 1 (Continued)

\begin{tabular}{|c|c|c|c|c|c|c|c|c|c|c|}
\hline $\begin{array}{l}\text { sample } \\
\text { name }\end{array}$ & $\begin{array}{l}\text { sampling } \\
\text { point }\end{array}$ & $\begin{array}{l}\text { sampling } \\
\text { date }\end{array}$ & $\begin{array}{c}\text { TN } \\
\text { wt } \%\end{array}$ & $\begin{array}{l}\text { TOC } \\
\text { wt } \%\end{array}$ & $\begin{array}{c}\mathrm{TOC} / \mathrm{TN} \\
\text { atomic } \\
\text { ratio }\end{array}$ & $\begin{array}{c}\text { TS } \\
\text { wt } \%\end{array}$ & $\underset{\%}{\delta_{0}^{34} \mathrm{~S}}$ & $\begin{array}{l}\text { Total As content } \\
\text { (Tsuchiya et al., } \\
2012 \text { ) mg/kg }\end{array}$ & & Japanese address \\
\hline RY24 & 61 & 2011.8 .2 & 0.10 & 1.07 & 12.9 & 0.06 & & 5.9 & 宮城県 & 本吉郡南三陸町歌津港 \\
\hline RY23 & 62 & 2011.8.2 & 0.07 & 0.43 & 7.6 & 0.01 & & 8.6 & 宮城県 & 本吉郡南三陸町歌津伊里前 \\
\hline NT1 & 63 & 2011.6 .4 & 0.23 & 3.16 & 16.0 & 0.03 & & 5.1 & 宮城県 & 本吉郡南三陸町志津川清水浜 \\
\hline NT3 & 64 & 2011.6 .4 & 0.20 & 2.47 & 14.6 & 0.11 & & 13.0 & 宮城県 & 本吉郡南三陸町志津川小森 \\
\hline NT2 & 65 & 2011.6 .4 & 0.04 & 0.55 & 14.4 & 0.17 & & 9.5 & 宮城県 & 本吉郡南三陸町志津川五日町 \\
\hline NT4 & 66 & 2011.6 .4 & 0.07 & 0.79 & 13.6 & 0.07 & & 7.7 & 宮城県 & 本吉郡南三陸町戸倉川向 \\
\hline NT7 & 67 & 2011.6 .4 & 0.16 & 1.94 & 13.8 & 0.03 & & 13.3 & 宮城県 & 本吉郡南三陸町戸倉滝浜 \\
\hline NT6 & 68 & 2011.6.4 & 0.13 & 1.97 & 17.7 & 0.28 & -16.4 & 14.6 & 宮城県 & 本吉郡南三陸町戸倉新中芝 \\
\hline NT5 & 69 & 2011.6 .4 & 0.32 & 4.24 & 15.6 & 0.06 & & 17.7 & 宮城県 & 本吉郡南三陸町戸倉上沢前 \\
\hline NT17 & 70 & 2011.7 .2 & 0.04 & 0.74 & 20.5 & 0.03 & & 5.4 & 宮城県 & 石巻市北上町十三浜相川 \\
\hline Tnm-03 & 71 & 2011.4.16 & 0.10 & 1.42 & 17.2 & 0.04 & & 5.7 & 宮城県 & 石巻市北上町十三浜白浜 \\
\hline NT16 & 72 & 2011.7 .2 & 0.04 & 0.75 & 20.2 & 0.11 & & 10.9 & 宮城県 & 石巻市北上町十三浜原 \\
\hline Tnm-02 & 73 & 2011.4.16 & 0.27 & 3.04 & 13.2 & 0.45 & +5.0 & 21.0 & 宮城県 & 石巻市北上町女川二丁谷地 \\
\hline NT18 & 74 & 2011.7 .2 & 0.01 & 0.25 & 28.9 & 0.05 & & 10.1 & 宮城県 & 石巻市針岡小谷地 \\
\hline NT15 & 75 & 2011.7 .2 & 0.03 & 0.51 & 22.9 & 0.05 & & 9.7 & 宮城県 & 石巻市中野牧野巣前 \\
\hline Tnm-01 & 76 & 2011.4.16 & 0.03 & 0.69 & 28.8 & 0.12 & & 8.8 & 宮城県 & 石巻市相野谷 \\
\hline NT19 & 77 & 2011.7 .2 & 0.11 & 1.99 & 20.2 & 0.42 & -29.6 & 11.1 & 宮城県 & 石巻市雄勝町下雄勝 1 丁目 \\
\hline NT21 & 78 & 2011.7 .2 & 0.08 & 1.20 & 18.2 & 0.04 & & 5.6 & 宮城県 & 牡鹿郡女川町御前浜御前 \\
\hline NH34 & 79 & 2011.6 .12 & 0.09 & 1.05 & 13.5 & 0.15 & & 6.0 & 宮城県 & 牡鹿郡女川町女川浜女川 \\
\hline NH33 & 80 & 2011.6 .12 & 0.02 & 0.34 & 21.8 & 0.02 & & 3.5 & 宮城県 & 牡鹿郡女川町野々浜大道 \\
\hline $\mathrm{NH} 24$ & 81 & 2011.6 .12 & 0.06 & 0.98 & 17.8 & 0.14 & & 6.0 & 宮城県 & 石巻市桃浦 \\
\hline NH25 & 82 & 2011.6.12 & 0.14 & 2.01 & 17.1 & 0.61 & -23.3 & 9.7 & 宮城県 & 石巻市荻浜荻浜 \\
\hline NH32 & 83 & 2011.6 .12 & 0.01 & 0.28 & 24.0 & 0.09 & & 5.4 & 宮城県 & 石巻市大谷川浜二重坂 \\
\hline NH31 & 84 & 2011.6 .12 & 0.05 & 0.62 & 13.4 & 0.03 & & 6.5 & 宮城県 & 石巻市谷川浜川原 \\
\hline NH26A & 85 & 2011.6.12 & 0.06 & 1.02 & 20.9 & 0.02 & & 4.8 & 宮城県 & 石巻市清水田浜須波田 \\
\hline NH26B & 86 & 2011.6 .12 & 0.02 & 0.25 & 17.8 & 0.01 & & 6.4 & 宮城県 & 石巻市清水田浜須波田 \\
\hline NH28 & 87 & 2011.6 .12 & 0.04 & 1.19 & 34.5 & 0.06 & & 3.8 & 宮城県 & 石巻市大原浜町 \\
\hline NH29A & 88 & 2011.6.12 & 0.01 & 0.14 & 16.2 & 0.04 & & 7.2 & 宮城県 & 石巻市十八成浜十八成 \\
\hline NH29B & 89 & 2011.6 .12 & 0.01 & 0.58 & 68.0 & 0.02 & & 10.0 & 宮城県 & 石巻市十八成浜十八成 \\
\hline Tnm-17 & 90 & 2011.4.29 & 0.06 & 0.59 & 12.1 & 0.11 & & 6.8 & 宮城県 & 石巻市鮎川浜南 \\
\hline NH22 & 91 & 2011.6.11 & 0.08 & 1.04 & 15.4 & 0.12 & & 12.9 & 宮城県 & 石巻市水明南 2 丁目 \\
\hline Tnm-04 & 92 & 2011.4.16 & 0.04 & 0.72 & 19.3 & 0.12 & & 7.2 & 宮城県 & 石巻市不動町 2 丁目 \\
\hline NH21 & 93 & 2011.6 .11 & 0.19 & 2.34 & 14.5 & 0.24 & & 14.8 & 宮城県 & 石巻市大街道西 3 丁目 \\
\hline NH23 & 94 & 2011.6 .12 & 0.01 & 0.32 & 37.0 & 0.05 & & 9.3 & 宮城県 & 石巻市緑町 2 丁目 \\
\hline NH20 & 95 & 2011.6 .11 & 0.28 & 3.16 & 13.2 & 0.14 & & 31.4 & 宮城県 & 東松島市大曲横沼 \\
\hline NH19 & 96 & 2011.6 .11 & 0.08 & 1.45 & 20.7 & 0.09 & & 8.8 & 宮城県 & 東松島市高松猪鼻 \\
\hline Tnm-08 & 97 & 2011.4 .16 & 0.25 & 3.02 & 14.1 & 0.09 & & 16.8 & 宮城県 & 東松島市牛網新上四十八 \\
\hline Tnm-16 & 98 & 2011.4.29 & 0.01 & 0.31 & 35.6 & 0.01 & & 2.6 & 宮城県 & 東松島市野蒜洲崎 \\
\hline NH17A & 99 & 2011.6.11 & 0.01 & 0.34 & 38.7 & 0.03 & & 2.3 & 宮城県 & 宮城郡松島町手樽早川東 \\
\hline NH17B & 100 & 2011.6.11 & 0.29 & 2.90 & 11.7 & 1.24 & -22.2 & 13.7 & 宮城県 & 宮城郡松島町手樽早川東 \\
\hline NH16 & 101 & 2011.6 .11 & 0.15 & 1.72 & 13.5 & 0.23 & & 5.2 & 宮城県 & 宮城郡松島町高城浜 \\
\hline NH15 & 102 & 2011.6 .11 & 0.27 & 3.25 & 13.9 & 0.61 & -22.8 & 12.6 & 宮城県 & 宮城郡松島町松島東浜 \\
\hline NH8A & 103 & 2011.6 .6 & 0.01 & 0.19 & 22.4 & 0.04 & & 6.3 & 宮城県 & 塩䆧市新浜町 1 丁目 \\
\hline NH8B & 104 & 2011.6 .6 & 0.15 & 1.79 & 14.0 & 0.56 & -15.5 & 9.7 & 宮城県 & 塩䆠市新浜町 1 丁目 \\
\hline Tnm-15 & 105 & 2011.4.29 & 0.01 & 0.13 & 14.0 & 0.04 & & 10.6 & 宮城県 & 宮城郡七ヶ浜町花㴊浜古舘 \\
\hline NH10 & 106 & 2011.6 .6 & 0.05 & 0.81 & 20.5 & 0.07 & & 8.1 & 宮城県 & 多賀城市栄 \\
\hline NH11 & 107 & 2011.6 .6 & 0.03 & 0.89 & 31.8 & 0.12 & & 9.7 & 宮城県 & 仙台市宮城野区白鳥 \\
\hline Tnm-14 & 108 & 2011.4.29 & 0.03 & 0.59 & 24.4 & 0.08 & & 9.6 & 宮城県 & 仙台市宮城野区蒲生町 \\
\hline NH12A & 109 & 2011.6 .6 & 0.32 & 5.52 & 20.1 & 0.10 & & 22.3 & 宮城県 & 仙台市若林区荒井遠藤 \\
\hline NH12B & 110 & 2011.6 .6 & 0.37 & 4.87 & 15.3 & 0.07 & & 11.5 & 宮城県 & 仙台市若林区荒井遠藤 \\
\hline Tnm-13 & 111 & 2011.4.29 & 0.07 & 1.05 & 16.6 & 0.04 & & 10.8 & 宮城県 & 仙台市若林区荒浜 \\
\hline NH14 & 112 & 2011.6 .6 & 0.03 & 0.70 & 27.9 & 0.04 & & 12.7 & 宮城県 & 名取市闒上太子堂 \\
\hline Tnm-12 & 113 & 2011.4 .25 & 0.01 & 0.52 & 47.7 & 0.03 & & 10.5 & 宮城県 & 名取市䦥上 2 丁目 \\
\hline $\mathrm{AO} 2$ & 114 & 2011.6 .13 & 0.12 & 2.20 & 20.6 & 0.09 & & 17.8 & 宮城県 & 岩沼市下野郷中谷地 \\
\hline $\mathrm{AO} 1$ & 115 & 2011.6 .13 & 0.01 & 0.12 & 14.4 & 0.02 & & 7.4 & 宮城県 & 岩沼市下野郷浜 \\
\hline $\mathrm{AO} 8$ & 116 & 2011.6 .13 & 0.05 & 1.26 & 30.6 & 0.06 & & 16.3 & 宮城県 & 岩沼市早股東砂押 \\
\hline $\mathrm{AO} 7$ & 117 & 2011.6 .13 & 0.16 & 3.33 & 25.0 & 0.05 & & 8.8 & 宮城県 & 亘理郡亘理町逢隈中泉原 \\
\hline $\mathrm{AO} 3 \mathrm{~B}$ & 118 & 2011.6 .13 & 0.05 & 0.93 & 21.4 & 0.08 & & 12.3 & 宮城県 & 岩沼市寺島毛下 \\
\hline Tnm-11 & 119 & 2011.4 .25 & 0.02 & 0.38 & 28.0 & 0.01 & & 10.6 & 宮城県 & 亘理郡亘理町荒浜築港通り \\
\hline $\mathrm{AO} 4 \mathrm{~A}$ & 120 & 2011.6 .13 & 0.01 & 0.46 & 43.6 & 0.16 & & 15.2 & 宮城県 & 亘理郡亘理町江下 \\
\hline $\mathrm{AO} 4 \mathrm{~B}$ & 121 & 2011.6 .13 & 0.03 & 0.73 & 28.7 & 0.13 & & 20.1 & 宮城県 & 亘理郡亘理町江下 \\
\hline AO5 & 122 & 2011.6 .13 & 0.03 & 0.07 & 2.9 & 0.01 & & 7.8 & 宮城県 & 亘理郡亘理町吉田須賀畑 \\
\hline Tnm-09 & 123 & 2011.4 .25 & 0.01 & 0.16 & 18.2 & 0.02 & & 8.0 & 宮城県 & 亘理郡山元町山寺浜 \\
\hline $\mathrm{AO} 6$ & 124 & 2011.6 .13 & 0.18 & 3.12 & 20.2 & 0.05 & & 9.6 & 宮城県 & 亘理郡山元町高瀬南耕土 \\
\hline AO16 & 125 & 2011.6 .20 & 0.02 & 0.27 & 20.7 & 0.02 & & 6.4 & 宮城県 & 亘理郡山元町坂元二又 \\
\hline $\mathrm{AO} 15$ & 126 & 2011.6 .20 & 0.08 & 0.89 & 13.2 & 0.03 & & 4.5 & 宮城県 & 亘理郡山元町坂元道合 \\
\hline Tnm-10 & 127 & 2011.4 .25 & 0.01 & 0.18 & 21.0 & 0.01 & & 1.1 & 福島県 & 相馬郡新地町埒木崎埒南浜田 \\
\hline $\mathrm{AO} 14$ & 128 & 2011.6 .20 & 0.01 & 0.27 & 33.4 & 0.04 & & 10.5 & 福島県 & 相馬市原釜北谷地 \\
\hline $\mathrm{AO} 13$ & 129 & 2011.6.20 & 0.14 & 2.46 & 20.3 & 0.06 & & 6.2 & 福島県 & 相馬市新沼 \\
\hline $\mathrm{AO} 12$ & 130 & 2011.6.20 & 0.02 & 0.54 & 31.3 & 0.04 & & 6.0 & 福島県 & 相馬市柏崎南家野 \\
\hline AO9 & 131 & 2011.6.20 & 0.18 & 3.39 & 22.1 & 0.08 & & 7.2 & 福島県 & 相馬市日下石鳥喰 \\
\hline AO11 & 132 & 2011.6.20 & 0.03 & 0.87 & 29.0 & 0.08 & & 5.6 & 福島県 & 相馬市蒲庭前釜 \\
\hline $\mathrm{AO} 10$ & 133 & 2011.6.20 & 0.16 & 2.56 & 18.4 & 0.16 & & 7.5 & 福島県 & 南相馬市鹿島区南柚木矢ノ目 \\
\hline
\end{tabular}


tivity detector: TCD）により検出される。本法に おける測定誤差は, すべての元素（窒素，炭素，

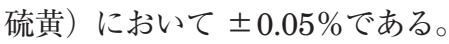

\section{3) 安定硫黄同位体分析 $\left(\boldsymbol{\delta}^{34} \mathbf{S}\right)$}

全硫黄濃度が $0.25 \mathrm{wt} \%$ 以上の試料を対象に，硫 黄同位体分析を行った $(n=19)$ 。岩手沿岸地域で 4 試料（NT12，RY04，RY05，RY08)，気仙沼地 域で 8 試料（NH1，NH2，NH3，NH7, NT29, NT30, NT31, Tnm-06), 南三陸町-石巻地域で 4 試料（NH25, NT6, NT29, Tnm-02), 仙台港沿 岸地域で 3 試料（NH8, NH15, NH17b）の試料 を用いて硫黄同位体測定を行った。

津波堆積物中の硫黄の化学形態分別を行ってい ないため，安定同位体分析へ供与する試料中には， 硫酸塩，硫化物および有機物態硫黄が存在してい る。ゆえに, 本研究における安定硫黄同位体比を, $\delta^{34} \mathrm{~S}_{\mathrm{TS}}$ （全硫黄（Total Sulfur）の安定硫黄同位体 比）として表記する。安定硫黄同位体分析には, 元素分析-同位体比質量分析計 (Isotope ratio mass spectrometer: IRMS, MAT252, Finnigan 社製）を用いた。試料を錫箔中に封入する際に, 助然剤として酸化バナジウム $\left(\mathrm{V}_{2} \mathrm{O}_{5}\right)$ を混ぜた。 元素分析計により $\mathrm{SO}_{2}$ ガス化された試料が，Conflo III を介してオンラインで IRMS へ導入される。 測定された同位体值は，国際標準試料であるキャ ニオンダイアブロ隕石 (Canyon Diabro Troilite: $\mathrm{CDT}$ ) 中の $\mathrm{FeS}$ の硫黄同位体比を用いて規格化し, 式（1）より測定試料の $\delta^{34} \mathrm{~S}_{\mathrm{TS}}$ を得た。

$$
\begin{aligned}
& \delta^{34} \mathrm{~S}(\%) \\
& =\left\{\left({ }^{34} \mathrm{~S} /{ }^{32} \mathrm{~S}\right)_{\text {sample }}\left({ }^{34} \mathrm{~S} /{ }^{22} \mathrm{~S}\right){ }_{\mathrm{CDT}}-1\right\} \times 10^{3}
\end{aligned}
$$

Laboratory standard として $\mathrm{Ag}_{2} \mathrm{~S}\left(\delta^{34} \mathrm{~S}=+0.54 \%\right.$ o を用いた。本法における測定誤差は, $\pm 0.5 \%$ である。

\section{III. 結果と考察}

既報（土屋ほか, 2012）にならい, 津波堆積物 試料を 4 つの地域（岩手沿岸，気仙沼，南三陸 町-石巻，仙台湾沿岸）に区別した（図 1)。津波 堆積物中の全窒素, 全有機態炭素, 全硫黄の含有 量，および $\delta^{34} \mathrm{~S}_{\mathrm{TS}}$ 測定結果を表 1 に示す。

\section{1）全窒素, 全有機態炭素, 全硫黄含有量}

1-1）岩手沿岸地域（Sampling points: 1-37） 津波堆積物中の全窒素 $(\mathrm{TN})$, 全有機態炭素 (TOC)，全硫黄含有量（TS）はそれぞれ0.01$0.38 \mathrm{wt} \% ， 0.11-4.94 \mathrm{wt} \% ， 0.01-0.65 \mathrm{wt} \%$ であっ た（図 2 , 表 1)。全硫黄含有量の平均值は 0.13 wt\%（ $n=38 ）$ であり，釜石市大渡町（RY04）お よび釜石市港町（RY05）の試料において比較的高 い值（それぞれ $0.46 \mathrm{wt} \%$ ，および $0.65 \mathrm{wt} \%$ ）を 示した。

1-2）気仙沼地域（Sampling points: 38-60）

全窒素，全有機態炭素，全硫黄含有量はそれぞ れ 0.02-0.44 wt\%，0.27-2.52 wt\%，0.01-1.43 wt\%であった（図 2，表 1)。また，鉱さい試料 (NH1，NT30）の全硫黄含有量はそれぞれ 1.43 $\mathrm{wt} \%$ ，および $0.97 \mathrm{wt} \%$ を示し，その他の試料と比 較しておおむね高い全硫黄含有量をもつことがわ かった。全硫黄含有量の平均值は $0.37 \mathrm{wt} \%(n=$ 23）であり，その他 3 つのエリアと比べ明らかに 高い值を示した。とくに気仙沼市本吉町で得られ た試料は，その他の地点と比較して高い硫黄含有 量を示した（平均值で $0.52 \mathrm{wt} \%, n=14$ )。

1-3）南三陸町-石巻地域（Sampling points: 61-98)

全窒素, 全有機態炭素, 全硫黄含有量はそれぞ れ 0.01-0.27 wt\%, 0.14-4.24 wt\%, 0.01-0.61 wt\% であった（図 2，表 1)。南三陸町-石巻地域におけ る硫黄含有量は低い值を示し（平均值で $0.11 \mathrm{wt} \%$, $n=38), 3$ 試料のみ比較的高い硫黄含有量を示し た（Tnm-02, 0.45 wt\%; NT19, 0.42 wt\%; NH25, $0.61 \mathrm{wt} \%)$ 。

1-4）仙台湾沿岸地域（Sampling points: 99133)

全窒素，全有機態炭素，全硫黄含有量はそれぞ れ 0.01-0.27 wt\%，0.07-4.87 wt\%，0.01-1.24 wt\%であった（図 2, 表 1)。仙台湾沿岸地域にお ける全硫黄含有量の平均値は $0.13 \mathrm{wt} \%(n=35)$ を示し，3試料のみ比較的高い硫黄含有量を示し た (NH17B, $1.24 \mathrm{wt} \%$; NH15, $0.61 \mathrm{wt} \%$; NH8B, $0.56 \mathrm{wt} \%)$ 。 

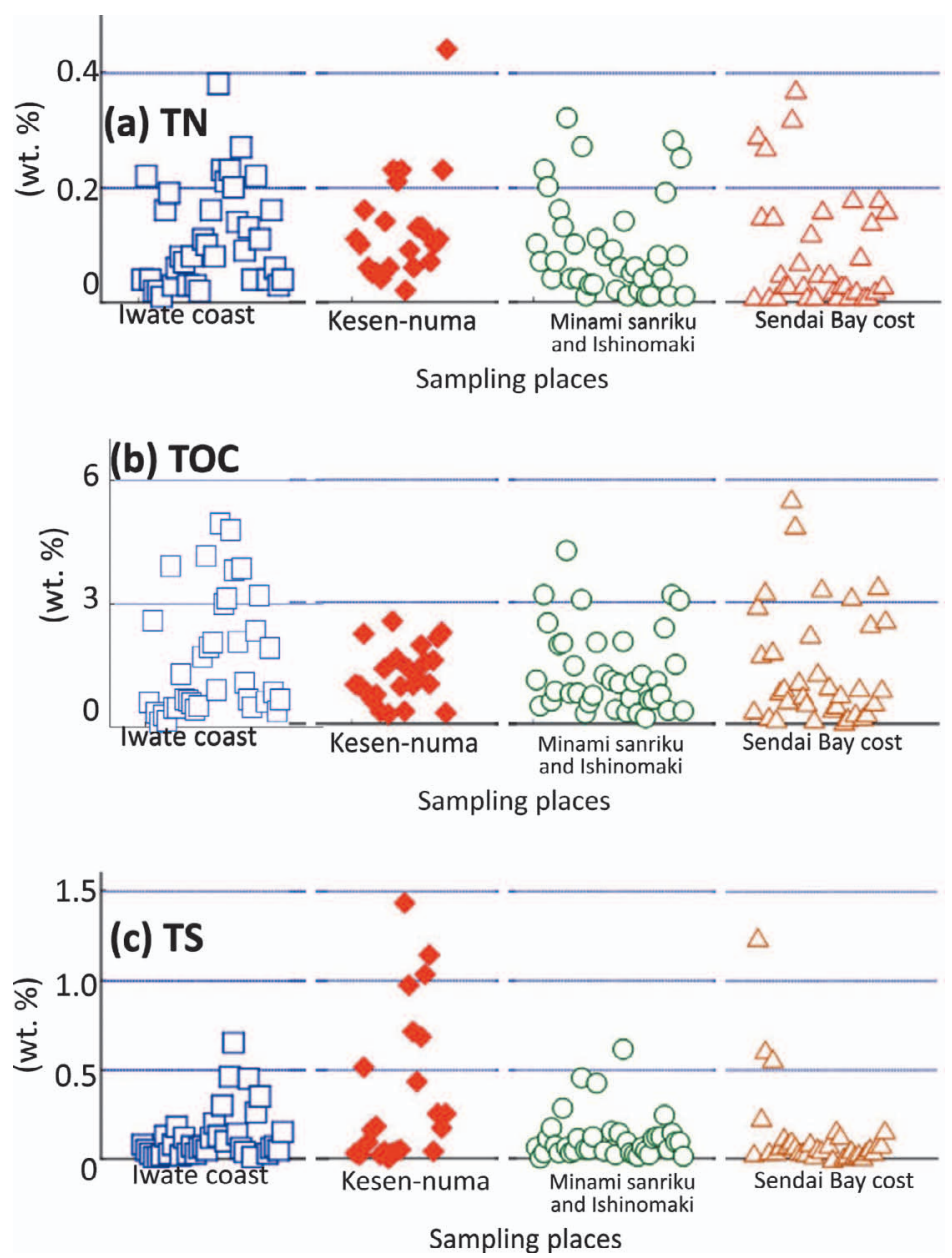

図 2 岩手沿岸, 気仙沼, 南三陸および 石巻, 仙台港地域における津波堆 積物試料中の a) TN, b) TOC, c) TS 濃度.

Fig. 2 Concentrations of a) TN, b) TOC, and c) TS of modern tsunami deposits in Iwate coast, Kesen-numa, Minamisanriku and Ishinomaki, and Sendai Bay coast.

\section{2）安定硫黄同位体分析結果}

安定硫黄同位体比 $\left(\delta^{34} \mathrm{~S}_{\mathrm{TS}}\right)$ は，すべての地域で $-29.6 \%$ から $+5.0 \%$ の範囲をもち，気仙沼地域を除 く 3 つの地域で低い $\delta^{34} \mathrm{~S}_{\mathrm{TS}}$ 值を示した（平均值で 岩手沿岸地域: $-16.0 \%$, 南三陸地域 : $-16.5 \%$, および仙台港沿岸地域：-20.1\%)。一方，気仙沼 地域では平均值で $-2.5 \%$ の比較的重い值を示し, 気仙沼地域で採取した鉱さい試料の $\delta^{34} \mathrm{~S}_{\mathrm{TS}}$ 值は, -3.31\%（NH1）と-0.96\%。（NT30）であった。

2011 年東北地方太平洋沖地震津波堆積物試料 の安定硫黄同位体比は，仙台平野にて採取された 試料を対象に Chagué-Goff et al. (2012) により 報告されている。仙台平野試料の安定硫黄同位体 比は, 本研究で得られた $\delta^{34} \mathrm{~S}_{\mathrm{TS}}$ と比較して非常
に高い(約 $+19 \sim+20 \%, n=5$, Chagué-Goff et al., 2012)。これは, Chagué-Goff et al. (2012) が，津波堆積物試料中の硫酸塩を対象とした安定 硫黄同位体比分析を行ったため, 海水由来の硫酸 塩中の安定硫黄同位体比（約 $+20 \%$ ）に影響さ れていることによる。つまり本研究における津波 堆積物試料中の硫黄は, 海水由来硫酸塩の影響が 非常に低い。また，東北地方の沿岸域にはとくに 仙台平野において, 水田や田畑などの農耕用地が 点在している。津波により農地が巻き上げられ， 農耕用地土㙵由来の硫黄が津波堆積物として堆積 することも考えられる。しかしながら水田や田畑 に使用される化学合成肥料中の硫黄同位体比は $-4.9 \sim+10.2 \%$ と報告されており（Mizota and 
Sasaki 1996)，この值を比較して，気仙沼試料 を除いた本研究試料の $\delta^{34} \mathrm{~S}_{\mathrm{TS}}$ は明らかに低い值 である。本研究試料中の硫黄の供給源として, 農 業用地土壤由来の硫黄による影響は無視できるほ ど小さいといえる。

\section{3）津波堆積物に含まれる有機物の起源}

津波堆積物中の TOC および TN は，高い相関 を示した $(r=0.801$, 図 3a)。また, TOC と TN の相関から得られた近似式より，切片が 0 に非常 に近い值（0.019）をもつことがわかる。この結 果から, 本研究における津波堆積物試料に含まれ る窒素化合物のほとんどが有機物態の窒素であ り, 津波堆積物試料への無機態窒素の混入は無視 できるほど少ないことを示している。また TOC と $\mathrm{TN}$ の元素比（TOC/TN 比）は， $0.7 \sim 90.2$ と非常に幅広い值をもつが (表 1)，TOC/TN の 頻度分布から（図 4), TOC/TN 比が $10 \sim 30$ の 值をもつ試料が全体の $80 \%$ 以上を占めることが わかった。湖底抒よび海底堆積物中の TOC/TN 比は，堆積物中に含まれる有機物の起源を推定す る際に指標としてよく用いられている（Meyers， 2003)。通常, 湖水や海水など水環境中の植物プ ランクトン（一次生産者）は，炭素に対して窒素 をより多く含むタンパク質を生体構成物として保 持していることから，植物プランクトンの TOC/ TN 比はおよそ 4 10 の幅で推移する（Meyers, 2003)。一方，陸上高等植物は，リグニンやセル ロースといった炭素を多く含んだ有機分子で構成 されているため，その TOC/TN 比は非常に高い (40〜 160, Meyers, 1994)。ゆえに湖底や海洋堆 積物中の TOC/TN 比から, 湖内・海洋起源有機 物（自生性有機物）と陸起源有機物（外来性有機 物）の混合割合を見積もることができる（Perdue and Koprivnjak, 2007)。本研究によって得られ た，津波堆積物試料の比較的高い TOC/TN 比 (10 〜 30）から，津波堆積物中には陸起源有機物が 含まれていることが予想される。岩手県大桘湾お よび仙台平野における海洋底の表層堆積物中の TOC/TN 比は，それぞれ $8.5 \sim 18.6$ (平均值で 13.8土3.3; 和田ほか, 1984; Wada et al., 1987）お よび約 $8 \sim 12$ (Saito et al., 1989; Ikehara et al.,
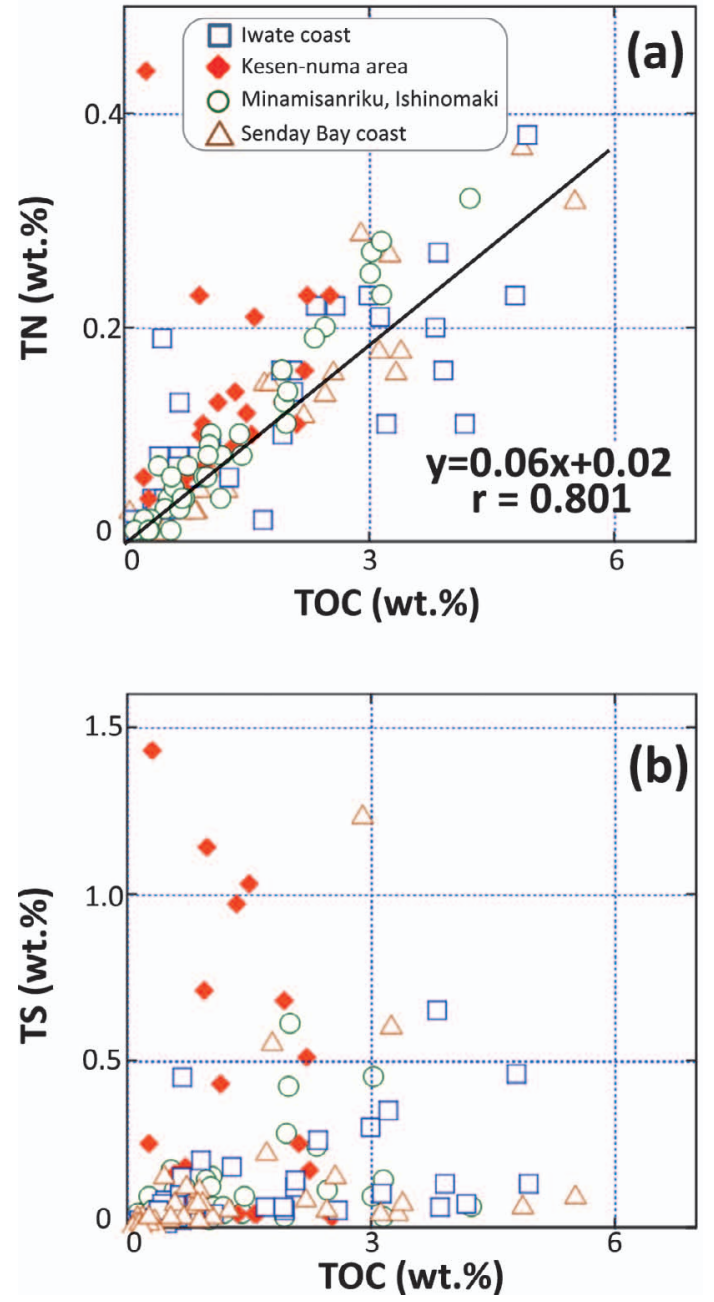

図 3 津波堆積物試料の a) TN および TOC 濃度の相 関図，b）TS およびTOC 濃度の相関図.

Fig. 3 Correlations between a) TN and TOC concentrations, and b) TS and TOC concentrations of tsunami deposits.

2014）であると報告されており，これらの值は陸 起源有機物の寄与を示している。つまり東北沖太 平洋沿岸の海洋堆積物は, 河川経由にて沿岸域へ と運搬された陸起源有機物の寄与があるといえる。 実際，和田ほか（1984）は大桘湾および大桘湾へ の流入河川（大桘川，小桘川，鵜住居川）の表層 堆積物中の TOC, TN 含有量，およびこれらの安 定同位体比分析を行い，大槌湾表層堆積物中の有 機物には，陸起源有機物が約 $30 \%$ 以上含まれてい 


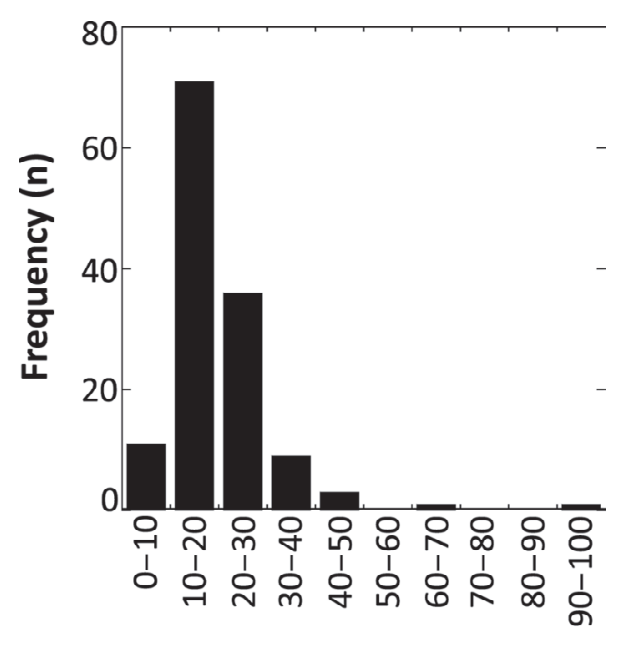

\section{$\mathrm{C} / \mathrm{N}$ atomic ratio}

図 4 津波堆積物試料の TOC/TN 比の頻度分布.

Fig. 4 Frequency distribution of TOC/TN atomic ratio in tsunami deposits.

ることを報告している。

堆積物中の有機物は, 堆積後の続成作用により 分解を受ける。その際に陸起源有機物であるリグ ニンやセルロースより，窒素を含むタンパク質が 優先的に分解されるため, 堆積物中の有機態窒素 が有機態炭素に比べ優先的に無機化を受ける。こ れにより，堆積物中の TOC/TN 比の鉛直分布は 深度方向に対して増加傾向を示す (Saito et al., 1989）。つまり，津波堆積物中の比較的高い TOC/ $\mathrm{TN}$ 比（約 $20 \sim 30 ）$ は，津波による巻き上げ時 において海洋底の表層堆積物がより深部まで巻き 上げられた，あるいは陸地へ輸送された後に起き た続成作用により，その值を増加させたと考えら れる。よって，TOC/TN 比が $10 〜 30$ の值をもつ 津波堆積物試料に含まれる有機物の起源は, 海洋 底の表層に堆積した有機物（河川からの陸起源有 機物と海洋表層で生産された自生性有機物の混 合）であるといえる。この結果は，河川を経由し て陸域から海洋沿岸へいったん運ばれた有機物 が, 津波によって再度, 海底から陸域へと運搬さ れる物質輸送が生じていることを示している。

\section{4）津波による海洋表層堆積物の輸送}

津波堆積物中の硫黄含有量（TS）は, 気仙沼地
域を除いて，全有機態炭素量（TOC）とおおむね

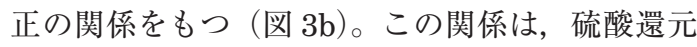
バクテリア（Sulfate reducing bacteria: SRB）の 活動による有機物分解と硫化物生成で説明でき る。海洋堆積物中において還元環境が進行する と, 硫酸還元バクテリアによる有機物分解が行わ れる。その際，電子受容体として間隙水中の硫酸 イオン $\left(\mathrm{SO}_{4}{ }^{2-}\right)$ が利用され，下記の反応式に従 い硫化水素 $\left(\mathrm{H}_{2} \mathrm{~S}\right)$ を発生し, 最終的に環境中の $\mathrm{Fe}^{2+}$ と反応し黄鉄鉱 (Pyrite: $\mathrm{FeS}_{2}$ ) として堆積 物中に留まる。

$$
\begin{gathered}
2 \mathrm{CH}_{2} \mathrm{O}-\mathrm{R}(\text { 有機物 })+\mathrm{SO}_{4}{ }^{2-} \\
=\mathrm{H}_{2} \mathrm{~S}+2 \mathrm{HCO}_{3}{ }^{-}+2 \mathrm{R} \\
\mathrm{Fe}^{2+}+\mathrm{H}_{2} \mathrm{~S}=\mathrm{FeS}+2 \mathrm{H}^{+} \\
\mathrm{FeS}+\mathrm{H}_{2} \mathrm{~S}=\mathrm{FeS}_{2}+2 \mathrm{H}^{+}
\end{gathered}
$$

海水中, および海洋堆積物表層の間隙水中には, 硫酸イオン $\left(\mathrm{SO}_{4}{ }^{2-}\right)$ が豊富に存在し，かつ $\mathrm{Fe}$ も堆積物中に十分に含まれているため，硫酸還元 バクテリアの活動を規定しているのは堆積物表層 に降り積もる有機物 $\left(\mathrm{CH}_{2} \mathrm{O}-\mathrm{R}\right)$ である。気仙沼 地域以外の津波堆積物試料の TOC と TS の正の 関係性は，堆積物中の TS（黄鉄鉱）の蓄積が TOC（有機物）に律速されていることを表して いるといえ, 気仙沼地域以外の津波堆積物中の硫 黄は，海洋堆積物中で起きた硫酸還元により生成 された黄鉄鉱であると考えられる。

硫酸還元バクテリアにより $\mathrm{SO}_{4}{ }^{2-}$ が $\mathrm{H}_{2} \mathrm{~S}$ 一還 元される際，高い同位体分別が起き，軽い硫黄同 位体 $\left.{ }^{32} \mathrm{~S}\right)$ をもった $\mathrm{SO}_{4}{ }^{2-}$ が $\mathrm{H}_{2} \mathrm{~S}$ へとより多く 還元される（最大約 $-40 \%$, Habicht and Canfield 1997)。一方, $\mathrm{H}_{2} \mathrm{~S}$ から $\mathrm{FeS}_{2}$ が形成される 際の同位体分別は非常に小さいため，軽い硫黄同 位体比をもった $\mathrm{FeS}_{2}$ が堆積物中に保存される。 ゆえに, 気仙沼地域以外の津波堆積物試料中の軽 い硫黄同位体比（-29.6〜-11.3\%o, 図 5) は, これらの試料中の硫黄が, 海洋堆積物中での還元 環境下における硫酸還元バクテリアの活動により 
生成した黄鉄鉱で形成されていることを強く示 す。TOC/TN 比で得られた結果と同様に TSおよ び $\delta^{34} \mathrm{~S}_{\mathrm{TS}}$ の結果からも，本研究にて採取された 津波堆積物試料は，津波により陸域へと運搬され た海底表層堆積物で構成されていることを強く示 している。さらにこの結果は, 歴史津波堆積物を 判別する際に, 海岸からの砂ではなくさらに粒度 の細かい海洋底泥が重要であるとする, Goto et $a l$. (2011) の指摘を支持している。

5）硫黄同位体比が示す気仙沼地域津波堆積物 中のヒ素の起源

気仙沼地域の津波堆積物中の TS は，TOC に対 して非常に高い值（最大約 $1.4 \mathrm{wt} \%$ ）を示し（図 3b)，TOC に対してTSの濃縮が起きている。堆 積物中の硫酸還元バクテリアの活動が非常に活発 化すると，有機物（TOC）に対して硫黄（TS）の 濃縮が発生する場合がある。しかしながらこの地 域における $\delta^{34} \mathrm{~S}_{\mathrm{TS}}$ は，高い值 $(-3.31 \sim-0.63 \%$ 。 を示し，硫酸還元による硫黄濃縮は考えにくい。 津波堆積物試料の $\delta^{34} \mathrm{~S}_{\mathrm{TS}}$ より, 気仙沼本吉町地域 における津波堆積物試料中の硫黄の供給源は, 他 の地域における津波堆積物試料の硫黄供給源とは 異なることがわかった。

気仙沼市本吉町地域の津波堆積物試料中の元素 濃度の異常値は，七素（As）においても報告されて いる（土屋ほか, 2012)。気仙沼市および本吉郡にお いては，七素を含有する金属鉱床が密集しており (図 1)，かねてから鉱床由来のヒ素污染リスクが懸 念されていた（土屋ほか, 2007）。土屋ほか（2012） は, 気仙沼本吉町地域の津波堆積物試料中にヒ素 （As）が非常に高濃度（227～2563 ppm）含まれ ていること, また, 公定法 (環境省告示第 18 号試 験土畩溶出量調査に係る測定方法を定める件）に順 次した水溶出試験において, 気仙沼地域で採取され た津波堆積物試料中のヒ素溶出量が環境基準值 $(10 \mu \mathrm{g} / \mathrm{l})$ を大幅に超過する $(51 \sim 391 \mu \mathrm{g} / \mathrm{l})$ こと を明らかにした。ゆえに, 津波堆積物試料中の七素 の供給源を明らかにすることは，七素の環境污染リ スクを正確に評価するために非常に重要である。

気仙沼地域における津波堆積物試料中の全硫黄 量（TS）と七素濃度は，その他の地域と比べて非
常に高い相関を示した $\left(r^{2}=0.918\right.$, 図 6)。これ は気仙沼地域にて採取された津波堆積物中のヒ素 と硫黄の起源が等しいことを示している。気仙沼 本吉町地域の津波堆積物試料, および鉱さい試料 の $\delta^{34} \mathrm{~S}_{\mathrm{TS}}$ は, 気仙沼地域以外で採取された津波堆 積物試料と比較して明らかに異なり，重い值をも つ（図 5, 表 1)。気仙沼市本吉町には，熱水性金 鉱床である大谷鉱山が開発され，その金鉱床中に は多くの硫化鉱物（黄鉄鉱，黄銅鉱や硫砒鉄鉱な ど）が随伴される（山田ほか, 2010）。東北地方北 部の金鉱床から採取された硫化鉱物中の安定硫黄 同位体比は，+2.5〜 + $6.9 \%$ であり（山田ほか, 2010), 気仙沼地域における津波堆積物試料中の $\delta^{34} \mathrm{~S}_{\mathrm{TS}}$ と近い值を示す。これらの結果は, 気仙沼 本吉地域において採取された津波堆積物試料中の 硫黄が，熱水由来の硫化物であることを示してい る。以上のことから，気仙沼地域にて採取された 津波堆積物中の硫黄, および硫黄と密接に関係し て硫化鉱物を構成するヒ素は, 鉱山跡地の堆積場 から流出した鉱さいに起源をもつと結論できる。

\section{IV. 結 論}

津波堆積物の元素分析および安定硫黄同位体比 $\left(\delta^{34} \mathrm{~S}_{\mathrm{TS}}\right)$ 分析より, 2011 年東北地方太平洋沖地 震によって岩手県, 宮城県, 福島県沿岸に打ち上 げられた津波堆積物の供給源を明らかにした。津 波堆積物試料の TOC/TN 比は, ほとんどの試料 において 10-30の間の值を示し， $\delta^{34} \mathrm{~S}_{\mathrm{TS}}$ は，気 仙沼地域以外の試料で非常に軽い值 $(-26.9$ か ら-11.3\%o）を示した。これらの結果から，一部 の津波堆積物試料の供給源は海洋底の表層堆積物 であり,さらに河川経由にて陸から海へ輸送され 海洋底表層に堆積した有機物が, 津波によって再 度, 海洋底表層から陸へと再運搬される物質輸送 が起きていることが示唆された。気仙沼本吉地域 にて採取された津波堆積物試料の TS はヒ素含有 量と非常に高い相関 $(r=0.958)$ を示し, 本地 域における津波堆積物試料中の硫黄とヒ素が同一 の起源をもつことがわかった。さらに気仙沼本吉 地域の津波堆積物試料の $\delta^{34} \mathrm{~S}_{\mathrm{TS}}$ 分析より, その 起源が熱水由来の硫化物である可能性が非常に高 


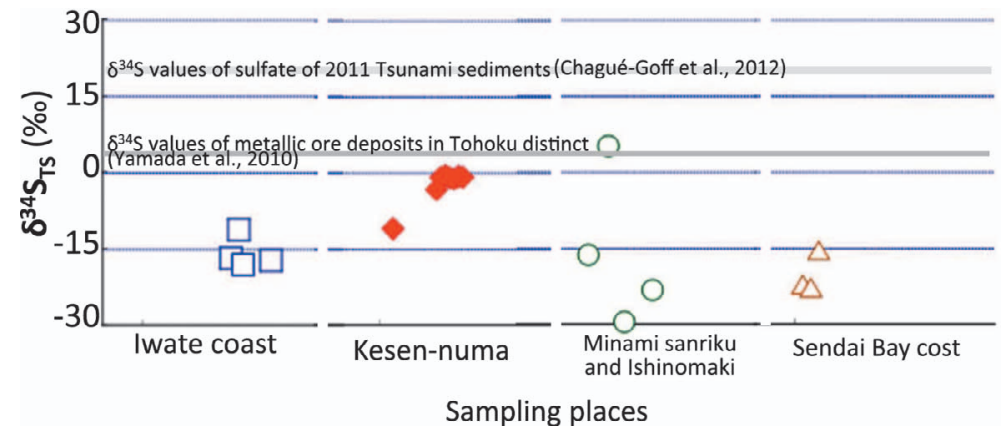

図 5 津波堆積物試料中の安定硫黄同位体比分布. 灰色で記した帯は仙台平野現世津波堆積物試料の安定硫黄 同位体比 (Chagué-Goff et al., 2012）および東北地方鉱山にて採取された硫化物中の硫黄同位体比を示す (山田ほか, 2010).

Fig. 5 Stable sulfur isotope ratios of tsunami deposits samples. Gray lines indicate stable sulfur isotope ratios of sulfate in the modern tsunami sediments at Sendai Plain (Chagué-Goff et al., 2012) and of sulfide in metallic ore deposits in Tohoku district (Yamada et al., 2010).

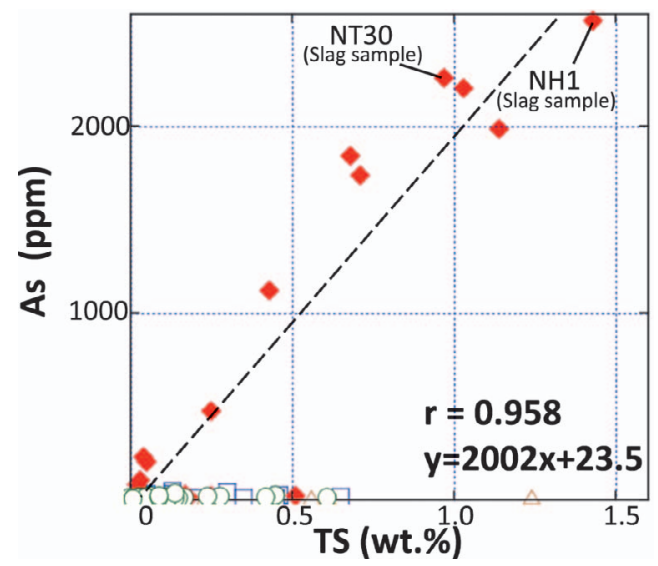

図 6 津波堆積物試料の TS およびAs 濃度の相関図.

Fig. 6 Correlation between TS and As concentration of tsunami deposits.

いことがわかった。よって，気仙沼本吉地域の津 波堆積物中に含まれる硫黄，およびヒ素は鉱山活 動に伴って海にもたらされ，津波とともに陸上へ 再度打ち上げられた可能性が示唆される。

\section{謝 辞}

本研究を遂行するにあたり，津波堆積物試料採取に おいて被災地域における周辺住民の方々，復興に携わ る多くの方々から協力をいただき，深く感謝申し上げ る。慶應義塾大学の故鹿園直建名誉教授には本特集号 へ寄稿する機会を与えていただいた。査読者として貴 重なコメントをいただいた産業総合研究所の藤原治
博士，および 1 名の匿名査読者に深く感謝する。本研 究は, JST/RISTEX 研究開発成果実装支援プログラム 「津波堆積物の地球化学的判別による沿岸地域のリスク 評価と社会的影響の予測」(実装責任者 土屋範芳), および JSPS 科研費（挑戦的萌芽研究 No.25630410 研究代表者 渡邊隆広）の助成を受けた。

\section{文献}

Chagué-Goff, C., Andrew, A., Szczucinski, W., Goff, J. and Nishimura, Y. (2012): Geochemical signatures up to the maximum inundation of the 2011 Tohokuoki tsunami: Implications for the 869 AD Jogan and other palaeotsunamis. Sedimentary Geology, 282, 65-77.

藤原 治 (2007): 地震津波堆積物 : 最近 20 年間のおも な進展と残された課題. 第四紀研究，46，451-462.

[Fujiwara, O. (2007): Seismic tsunami deposits: Major advances over the last 20 years and remaining problems. Quaternary Research, 46, 451-462. (in Japanese with English abstract) ]

藤原 治 - 佐藤善輝 - 小野映介 - 海津正倫 (2013) : 陸上掘削試料による津波堆積物の解析一浜名湖東岸 六間川低地にみられる 3400 年前の津波堆積物を例に して一. 地学雑誌, 122, 308-322. [Fujiwara, O., Sato, Y., Ono, E. and Umitsu, M. (2013): Researches on tsunami deposits using sediment cores: $3.4 \mathrm{ka}$ tsunami deposit in the Rokken-gawa Lowland near Lake Hamana, Pacific coast of central Japan. Journal of Geography (Chigaku Zasshi), 122, 308-322. (in Japanese with English abstract) ]

Goto, K., Chagué-Goff, C., Fujino, S., Goff, J., Jaffe, B., Nishimura, Y., Richmond, B., Sugawara, D., Szczucinski, W., Tappin, D.R., Witter, R.C. and Yulianto, E. (2011): New insights of tsunami hazard from 
the 2011 Tohoku-oki event. Marine Geology, 290, 46-50.

Habicht, K.S. and Canfield, D.E. (1997): Sulfur isotope fractionation during bacterial sulfate reduction in organic-rich sediments. Geochimica et Cosmochimica Acta, 61, 5351-5361.

Ikehara, K., Irino, T., Usami, K., Jenkins, R., Omura, A. and Ashi, J. (2014): Possible submarine tsunami deposits on the outer shelf of Sendai Bay, Japan resulting from the 2011 earthquake and tsunami off the Pacific coast of Tohoku. Marine Geology, 349, 91-96.

Meyers, P.A. (1994): Preservation of elemental and isotopic source identification of sedimentary organic matter. Chemical Geology, 114, 289-302.

Meyers, P.A. (2003): Applications of organic geochemistry to paleolimnological reconstructions: A summary of examples from the Laurentian Great Lakes. Organic Geochemistry, 34, 261-289.

Minoura, K. and Nakaya, S. (1991): Traces of tsunami preserved in inter-tidal lacustrine and marsh deposits: Some examples from northeastern Japan. Journal of Geology, 99, 265-287.

Mizota, C. and Sasaki, A. (1996): Sulfur isotope composition of soils and fertilizers: Differences between Northern and Southern hemispheres. Geoderma, 71, 77-93.

Perdue, E.M. and Koprivnjak, J.F. (2007): Using the $\mathrm{C} / \mathrm{N}$ ratio to estimate terrigenous inputs of organic matter to aquatic environments. Estuarine, Coastal and Shelf Science, 73, 65-72.

Saito, Y., Nishimura, A. and Matsumoto, E. (1989): Transgressive sand sheet covering the shelf and upper slope off Sendai North east Japan. Marine Geology, 89, 245-258.

澤井祐紀 · 岡村行信 - 宍倉正展 - 松浦旅人 - Than Tin Aung · 小松原純子・藤井雄士郎 (2006): 仙台平野の 堆積物に記録された歴史時代の巨大津波一1611 年慶 長津波と 869 年貞観津波の浸水域一。地質ニュース, 624, 36-41. [Sawai, Y., Okamura, Y., Shishikura, M., Matsuura, T., Aung, T.T., Komatsubara, J. and Fujii, Y. (2006): Historical tsunamis recorded in deposits beneath Sendai Plain: Inundation areas of the A.D. 1611 Keicho and the A.D. 869 Jogan tsunamis. Chishitsu News, 624, 36-41. (in Japanese)]

菅原大助・今村文彦・松本秀明 - 後藤和久 - 箕浦幸治 (2011): 地質学的データを用いた西暦 869 年貞観地震 津波の復元について. 自然災害科学，29，501-516. [Sugawara, D., Imamura, F., Matsumoto, H., Goto, K. and Minoura, K. (2011): Reconstruction of the AD 869 Jogan earthquake induced tsunami by using the geological data. Journal of Japanese Society of Natural Disaster Science, 29, 501-516. (in Japanese with English abstract)]

土屋範芳 - 狩野真吾 - 小川泰正 - 山田亮一 (2007): 地圈 における重金属類の分布と岩石からの移行プロセスに おける化学形態に関する基礎的検討. 地学雑誌, 116,
864-876. [Tsuchiya, N., Kano, S., Ogawa, Y. and Yamada, R. (2007): Fundamental study on distribution of heavy metals in the geosphere and their chemical species during transport processes from rocks. Journal of Geography (Chigaku Zasshi), 116 , 864-876. (in Japanese with English abstract) ]

土屋範芳 - 井上千弘 - 山田亮一 - 山崎慎一 - 平野伸夫 · 岡本 敦 - 小川泰正 - 渡邊隆広 - 奈良郁子 - 渡邊則昭 · 東北地方津波堆積物研究グループ (2012): 東北地方 太平洋沖地震による岩手, 宮城, 福島県沿岸域の津波 堆積物のヒ素に関するリスク評価. 地質学雑誌, 118, 419-430. [Tsuchiya, N., Inoue, C., Yamada, R., Yamasaki, S., Hirano, N., Okamoto, A., Ogawa, Y., Watanabe, T., Nara, F.W., Watanabe, N. and Tohoku Tsunami Sediment Research Group (2012): Risk assessments of Arsenic in tsunami sediments from Iwate, Miyagi and Fukushima Prefectures, Northeast Japan, by the 2011 off the Pacific coast of Tohoku Earthquake. Journal of the Geological Society of Japan, 118, 419-430. (in Japanese with English abstract)]

和田英太郎 - 水谷 広 - 柄沢享子 - 蒲谷裕子 - 南川雅男 . 米本昌平・过 堯 (1984): 大槌水系における有機物 の挙動: 炭素. 窒素同位体比からの評価. 地球化学, 18, 89-98. [Wada, E., Mizutani, H., Karasawa, K., Kabaya, Y., Minagawa, M., Yonemoto, S. and Tsuji, T. (1984): Carbon and nitrogen isotopic composition as tracers of transport of organic matter along the Otsuchi watershed. Chikyu Kagaku, 18, 89-98. (in Japanese with English abstract) ]

Wada, E., Minagawa, M., Mizutani, H., Tsuji, T., Imaizumi. R. and Karasawa, K. (1987): Biogeochemical studies on the transport of organic matter along the Otsuchi River watershed, Japan. Estuarine, Coastal and Shelf Science, 25, 321-336.

渡邊隆広・細田憲弘・土屋範芳 - 中村俊夫 ·平野伸夫 · 岡本 敦・奈良郁子・東北大学歴史津波調査グループ (2014): 仙台平野における歴史津波堆積物の放射性炭 素年代測定一連続土壤堆積物試料 HS シリーズの堆 積年代 (予察的分析) 一. 地学雑誌, 123, 904-922. [Watanabe, T., Hosoda, N., Tsuchiya, N., Nakamura, T., Hirano, N., Okamoto, A., Nara F.W. and Tohoku University Tsunami Sediment Research Group (2014): Radiocarbon dating of historical tsunami sediments from the Sendai plain, northeastern Japan: Preliminary age model for the HS continuous soil sediment series. Journal of Geography (Chigaku Zasshi), 123, 904-922. (in Japanese with English abstract) ]

山田亮一・吉田武義・掛川 武・奈良郁子 - 小川泰正 (2010): 東北地方北部の金属鉱床に随伴する高インジウム 鉱石の形成条件. 資源地質, 60, 153-164. [Yamada, R., Yoshida, T., Kakegawa, T., Nara, F. and Ogawa, Y. (2010): Several constraints of indium enrichment associated with base-metal, deposits in the vicinity of northern Tohoku district. Resource Geology, 60, 153-164. (in Japanese with English abstract) ] 